\title{
Optimasi Pembentuk Film Polivinil Alkohol dan Humektan Propilen Glikol pada Formula Masker Gel Peel off Sari Buah Labu Kuning (Cucurbita moschata Duchesne) sebagai Antioksidan
}

\author{
(Optimization of Film Forming Polyvinyl Alcohol and Propylene Glycol Humectant in \\ Pumpkin Juice (Cucurbita moschata Duchesne) Peel-off Gel Mask Formula as \\ Antioxidants)
}

\author{
Tricia Andini*, Yusriadi, Yuliet
}

Jurusan Farmasi, Fakultas MIPA, Universitas Tadulako, Palu

\author{
Article Info: \\ Received: 20 Juni 2017 \\ in revised form: 05 Juli 2017 \\ Accepted: 15 Juli 2017 \\ Available Online: 01Oktober 2017 \\ Keywords: \\ Pumpkin, \\ peel-off mask, \\ polyvinyl alcohol, \\ propylene glycol, \\ antioxidant
}

Corresponding Author:

Tricia Andini

Jurusan Farmasi Fakultas MIPA,

Universitas Tadulako, Palu,

Indonesia

Phone :+62-852-9819-6616

Email: tricia.andini@yahoo.com

\begin{abstract}
A research has conducted on the formulation in dosage forms gel peel-off masks. This study aims to determine the optimum concentration of polyvinyl alcohol as a film forming and propylene glycol as a humectant in the physical and chemical preparations of pumpkin juice peel-off gel mask, gel masks optimum formula stability and antioxidant activity of preparations. Obtained optimum formula is formula 1 with a PVA concentration of $10 \%$ and $10 \% \mathrm{PG}$ and then to evaluate the quality characteristics of the physical and chemical stability of the spread involved testing, $\mathrm{pH}$, viscosity and drying time. Observations were made each week for 4 weeks of storage at room temperature. Data were analyzed descriptively and statistically using paired sample t test. The results of the study gel mask peel-off at the optimum formula shows the preparation is stable during storage where no significant changes in each test parameter. The antioxidant activity of peel-off gel mask the relatively strong expressed by damping optimum percentage formula on day 2 was $75.18 \%$ and $73.37 \%$ at day 30 after storage at room temperature.
\end{abstract}




\section{ABSTRAK}

Telah dilakukan penelitian tentang formulasi dalam bentuk sediaan masker gel peel-off. Penelitian ini bertujuan untuk mengetahui konsentrasi optimum polivinil alkohol sebagai pembentuk film dan propilen glikol sebagai humektan terhadap sifat fisik dan kimia sediaan masker gel peel-off sari buah labu kuning, stabilitas formula optimummasker gel dan aktivitas antioksidan sediaan. Formula optimum yang didapatkan yaitu formula 1 dengan konsentrasi PVA 10\% dan PG 10\% kemudian dilakukan evaluasi karakteristik mutu fisik kimia dan stabilitas meliputi pengujian daya sebar, $\mathrm{pH}$, viskositas dan lama pengeringan. Pengamatan dilakukan tiap minggu selama 4 minggu penyimpanan pada suhu ruang. Data yang diperoleh dianalisis secara deskriptif dan secara statistik menggunakan metode paired sample $t$ test. Hasil penelitian masker gel peel-off pada formula optimum menunjukkan sediaan stabil selama penyimpanan dimana tidak terjadi perubahan yang signifikan pada tiap parameter uji. Aktivitas antioksidan gel masker peel-off tergolong kuat yang dinyatakan dengan peresen peredaman formula optimum pada hari ke- 2 adalah 75,18\% dan 73,37\% pada hari ke- 30 setelah penyimpanan pada suhu ruang.

Kata Kunci : Labu kuning, masker peel-off, polivinil alkohol, propilen glikol, antioksidan

\section{PENDAHULUAN}

Labu kuning (Cucurbita moschata Duchesne) merupakan bahan pangan yang mengandung kalori, karbohidrat, protein, lemak, mineral (kalsium, fosfor, besi, natrium, kalium, tembaga dan seng), ß-karoten, tiamin, niacin, serat dan vitamin C. Kandungan betakaroten merupakan sumber antioksidan dalam labu kuning yang mampu mencegah penuaan dini dan menghaluskan kulit. Penelitian Kandlakunta, et al (2008), menyatakan bahwa kandungan betakaroten pada labu kuning sebesar $1,18 \mathrm{mg} / 100 \mathrm{~g}$. $\beta$ karoten dapat meningkatkan produksi glikoaminoglikan dan procolagen, dimana kedua senyawa tersebut berperan dalam memperbaiki kondisi kulit dengan cara mempertahankan kelembaban dan membentuk jaringan baru yang lebih banyak sehingga membantu peremajaan sel-sel kulit (Coleman, 2009). Menurut penelitian Safitri, (2011) menyatakan bahwa labu kuning berpotensi sebagai pelembab kulit.

Beberapa penelitian menunjukkan buah labu kuning memiliki aktivitas antioksidan. Penelitian oleh Cahyanti (2013), menyatakan bahwa sari buah labu kuning mempunyai aktivitas antioksidan dengan persen peredaman sebesar $88,24 \%$. Penelitian lain oleh Wahyuni (2015) menyatakan bahwa ekstrak n-heksan buah labu kuning memiliki $\mathrm{IC}_{50}$ sebesar $134,17 \mathrm{ppm}$, dan total karotenoid sebesar 575,22 $\mu \mathrm{g} / \mathrm{g}$.

Potensi sari labu kuning sebagai antioksidan dan pelembab kulit dapat dimanfaatkan dalam bentuk sediaan masker gel peel-off. Sediaan masker gel peel-off, sangat praktis penggunaannya, setelah masker mengering akan dapat dibersihkan dengan cara mengangkat lapisan gel dari kulit tanpa perlu dibilas dengan air sehingga akan mempermudah penggunaan oleh konsumen.

Kualitas fisik masker gel peel-off dipengaruhi oleh komposisi bahan-bahan yang ditambahkan ke dalam formulasi. Dua komponen utama yang digunakan untuk membuat masker gel peel-off adalah pembentuk film dan humektan. Dalam formulasi gel, komponen pembentuk film merupakan faktor kritis yang dapat mempengaruhi sifat fisika gel yang dihasilkan (Rowe.,et al 2009). Selain itu, humektan juga berperan penting dalam sediaan gel karena humektan berfungsi untuk menjaga kestabilan sediaan dengan cara mengabsorbsi lembab dari lingkungan dan mengurangi penguapan air dari sediaan (Martin, 1993).

Polivinil alkohol digunakan sebagai pembentuk film yang banyak digunakan dalam sediaan topikal karena sifatnya biodegradable dan biocompatible (Ogur, 2005). Polivinil alkohol dapat meghasilkan gel yang cepat mengering dan membentuk lapisan film yang transparan, kuat, plastis dan melekat baik pada kulit. Propilen glikol merupakan salah satu humektan yang banyak digunakan pada sediaan kosmetik. Penggunaan propilen glikol diharapkan dapat meningkatkan stabilitas sediaan yang dihasilkan.

Berdasarkan uraian diatas, maka dalam penelitian ini digunakan variasi pembentuk film polivinil alkohol dan humektan propilen glikol untuk mengetahui pengaruhnya terhadap formulasi masker gel peel-off. 
Parameter yang diuji adalah mutu fisik dan kimia sediaan meliputi daya sebar, $\mathrm{pH}$, viskositas dan lama pengeringan. Formula optimum yang terpilih kemudian diuji stabilitas mutu fisik dan kimia sediaan dan menguji aktivitas antioksidannya.

\section{METODE PENELITIAN Bahan}

Bahan yang digunakan dalam penelitian adalah labu kuning, polivinil alkohol (kualitas farmasetik), propilen glikol (kualitas farmasetik), carbopol 940 (kualitas farmasetik), PEG-400 (kualitas farmasetik), trietanolamin (kualitas farmasetik), metil paraben (kualitas farmasetik), etanol 96\% (pro analisis), DPPH (pro analisis), aquades, kertas saring, aluminium foil, tisue.

\section{Jenis Penelitian}

Penelitian yang dilakukan merupakan jenis penelitian eksperimen laboratorium dan bersifat eksploratif, untuk mengetahui formula optimum masker gel peel-off sari buah labu kuning. Ada dua faktor yang diteliti efeknya yaitu konsentrasi Polivinil alkohol sebagai pembentuk film dan Propilen glikol sebagai humektan yang diuji terhadap sifat fisik dan kimianya.

\section{Pembuatan Serbuk Sari Buah Labu Kuning}

Buah labu kuning yang segar dicuci, dikupas kulitnya dan bijinya dibuang, kemudian daging buah labu kuning dipisahkan sari dan ampasnya dengan menggunakan juicer, lalu hasilnya dikeringkan dengan freezee dryer selama 24 jam pada suhu $-40^{\circ} \mathrm{C}$ dan tekanan 2 atm, sampai diperoleh serbuk kering.

\section{Uji sifat fisik dan kimia masker gel peel-off Uji Daya Sebar}

Sebanyak 1 gram gel diletakkan secara hati-hati diatas kaca berukuran 20x20 cm. Selanjutnya ditutupi dengan kaca yang lain dan digunakan pemberat diatasnya hingga bobot mencapai 125 gram, kemudian diukur diameternya setelah 1 menit.

\section{Uji Viskositas}

Pengujian dilakukan dengan menggunakan alat viskometer Brookfield digital dengan menggunakan spindel nomor 7 kemudian dicelupkan ke dalam gel dengan kecepatan putar sebesar $20 \mathrm{rpm}$ kemudian viskositas masker gel peel-off dapat terbaca pada layar monitor alat viskometer.

\section{Uji Lama Pengeringan}

Pengujian waktu kering dilakukan dengan cara mengoleskan gel sebanyak 0,1 gram secara merata dengan area pengolesan $2,5 \times 2,5$ $\mathrm{cm}$ dilengan tangan dan diamati waktu yang diperlukan sediaan mengering, yaitu waktu dari saat mulai dioleskannya masker gel hingga terbentuk lapisan yang kering dan elastis yang dapat dikelupas dari permukaan kulit tanpa meninggalkan massa gel.

\section{Uji pH Sediaan}

Alat terlebih dahulu dikalibrasi dengan menggunakan larutan dapar standar netral $(\mathrm{pH}$ $7,01)$ dan larutan dapar $\mathrm{pH}$ asam $(\mathrm{pH} 4,01)$ hingga alat menunjukkan harga $\mathrm{pH}$ tersebut. Kemudiaan elektroda dicuci dengan air suling, lalu dikeringkan dengan tissue. Sampel dibuat dalam konsentrasi $1 \%$ yaitu ditimbang 1 gram sediaan dan dilarutkan dalam $100 \mathrm{ml}$ air suling. Kemudian elektroda dicelupkan dalam larutan tersebut. Dibiarkan alat menunjukkan harga $\mathrm{pH}$ sampai konstan. Angka yang ditunjukkan $\mathrm{pH}$ meter merupakan $\mathrm{pH}$ sediaan.

\section{Uji Aktivitas Antioksidan masker gel peel- off}

Pengujian aktivitas antioksidan pada masker gelpeel-off terhadap radikal bebas DPPH menggunakan spektrofotometer UVVIS. Hal yang dilakukan adalah sampel gel sebanyak 0,5 gram dilarutkan dalam etanol pa hingga volumenya menjadi $25 \mathrm{ml}$, dimana konsentrasi yang diperoleh adalah 20.000 ppm. Lalu dipipet $0,1 \mathrm{ml}$ dilarutkan dengan etanol hingga $10 \mathrm{ml}$ didapatkan konsentrasi 200 ppm. Dipipet $4 \mathrm{ml}$, diencerkan ke dalam labu ukur dan dicukupkan dengan etanol pa hingga $10,0 \mathrm{ml}$ sehingga didapatkan konsentrasi terakhir $80 \mathrm{ppm}$. Larutan sampel dengan konsentrasi $80 \mathrm{ppm}$ dipipet sebanyak 1,0 ml ditambahkan 1,0 ml DPPH dan $2 \mathrm{ml}$ pelarut etanol pa kemudian diinkubasi dalam ruangan tertutup pada suhu $37^{\circ} \mathrm{C}$ selama 30 menit. Diukur serapannya dengan spektrofotometer UV-VIS pada pada panjang gelombang optimum hasil pengukuran yaitu $517 \mathrm{~nm}$. Pembanding yang digunakan pada penelitian ini yaitu masker gel peel-off yang mengandung betakaroten. 


\section{Analisis Data}

Data yang diperoleh dari uji sifat fisik dan kimia sediaan masker gel yang meliputi daya sebar, viskositas, $\mathrm{pH}$ dan lama pengeringan selanjutnya dihitung efek setiap perlakuan kombinasi dalam model Rancangan Acak Lengkap dengan ANOVA pada taraf kepercayaan 95\%. Jika hasil analisis varians berpengaruh nyata, maka dilanjutkan dengan uji lanjut formula optimum. Sedangkan untuk stabilitas sediaan gel masker, dapat dianalisis secara stastistik dengan menggunakan uji Paired samples t test.

Berdasarkan hasil ANOVA dapat diketahui signifikan dari setiap perlakuan kombinasi dalam mempengaruhi respon. Hipotesis nol $\left(\mathrm{H}_{0}\right)$ menyatakan bahwaperlakuan kombinasi antara polivinil alkohol dengan propilen glikol memiliki pengaruh yang tidak signifikan terhadap sifat fisik dan kimia sediaan gel. Sedangkan hipotesis awal $\left(\mathrm{H}_{1}\right)$ menyatakan perlakuan kombinasi antara polivinil alkohol dengan propilen glikol memiliki pengaruh yang signifikan terhadap sifat fisik dan kimia sediaan gel. $\mathrm{H}_{0}$ ditolak dan $\mathrm{H}_{1}$ diterima apabila diperoleh nilai probabilitas kurang dari 0,05.

\section{HASIL DAN PEMBAHASAN}

Labu kuning memiliki beberapa kandungan kimia diantaranya vitamin $\mathrm{C}$, flavanoid dan betakaroten yang bersifat sebagai antioksidan alami serta bermanfaat bagi kecantikan. Antioksidan adalah senyawa yang dapat menangkal atau meredam dampak radikal bebas yang dapat merusak kondisi kulit. Selain itu menurut penelitian Kandlakunta et al (2008) kandungan betakaroten yang terdapat pada labu kuning dapat meningkatkan produksi glikoaminoglikan dan procolagen, yang merupakan dua senyawa yang berperan dalam memperbaiki kondisi kulit dengan cara mempertahankan kelembaban dan membentuk jaringan baru yang lebih banyak sehingga membantu peremajaan sel-sel kulit. Oleh karena itu pada penelitian ini dibuat masker gel peel-off sari buah labu kuning sebagai antioksidan.

Proses ekstraksi dilakukan dengan menggunakan alat juicer. Metode inidipilih karena selain mudah untuk digunakan, kandungan yang terdapat dalam sampel tidak mengalami perubahan. Sari yang dihasilkan dari buah labu kuning dikeringkan dengan freeze dryer. Freeze dryer atau pengeringan beku merupakan salah satu metode yang mempunyai keunggulan dalam mempertahankan mutu hasil pengeringan karena dapat mempertahankan stabilitas produk dan struktur bahan. Serbuk buah labu kuning diuji aktivitas antioksidannya dengan metode DPPH dan diperoleh persen peredaman 86,59\%. Hal ini menunjukkan bahwa serbuk labu kuning termasuk dalam golongan antioksidan yang tinggi.

Penelitian ini bertujuan untuk mendapatkan konsentrasi komposisi optimum polivinil alkohol sebagai pembentuk film dan propilen glikol sebagai humektan. Untuk mencari nilai optimum dilakukan uji sifat fisik dan stabilitas sediaan masker gel peel off sari buah labu kuning (Cucurbita moschata Duchesne) setelah didiamkan selama 48 jam berkesetimbangan pada suhu ruang setelah pembuatan meliputi uji daya sebar, uji $\mathrm{pH}$, uji viskositas, dan uji lama pengeringan. Tujuan pengujian setelah 48 jam pembuatan agar hasil pengujian tidak terpengaruhi oleh faktor-faktor saat proses pembuatan sediaan gel masker. Proses pembuatan gel masker melibatkan penggunaan stirrer digital yang memberikan gaya yang besar terhadap sediaan. Setelah 48 jam diharapkan struktur tiga dimensi gel telah tertata dengan baik serta gelembung udara yang terjadi pada saat pembuatan telah hilang.

Pada pembuatan masker gel peel-off sari buah labu kuning sebagai antioksidan digunakan carbopol 940 sebagai gelling agent. pH Carbopol 940 bersifat asam yaitu 2-3 sedangkan sediaan yang dibuat membutuhkan $\mathrm{pH}$ yang mendekati $\mathrm{pH}$ kulit wajah yaitu 4,56,5. Viskositas karbopol juga tidak baik untuk diaplikasikan dikulit. Karena jika viskositas tinggi tidak akan memenuhi parameter sifat fisik yang diharapkan. Untuk menaikkan $\mathrm{pH}$ dan memperbaiki viskositas carbopol perlu ditambahkan dengan pemberian basa. Pada penelitian ini digunakan $0,5 \%$ trietanolamin. Pemberian trietanolamin menaikan $\mathrm{pH}$ carbopolmenjadi 5-6 sehingga tidak menyebabkan iritasi pada kulit, $\mathrm{pH}$ carbopol yang baik yaitu 6-11.

Dalam sediaan peel-off, salah satu faktor terpenting adalah pembentuk film, bahan yang dapat membuat lapisan tipis pada permukaan kulit beberapa saat setelah diaplikasikan sehingga memberikan sifat peel-off pada sediaan. Dalam penelitian ini digunakan polivinil alkohol sebagai pembentuk film. 
Menurut Buchmann, (2001) dalam sediaan gel dengan basis carbopol, diperoleh tipe hidrogel. Pada tipe ini perlu ditambahkan humektan untuk mencegah terjadinya evaporasi air yang berlebih, baik pada sediaan gel selama penyimpanan, maupun pada saat gel digunakan pada kulit. Selain itu peningkatan kelembaban juga akan mempengaruhi karakter lapisan yang dibentuk oleh polivinil alkohol. Dengan meningkatnya kelembaban akan dihasilkan lapisan yang lebih lembut dan fleksibel, sehingga memperbaiki karakteristik lapisan yang terbentuk. Humektan pada umumnya berwujud cair dan bersifat higroskopis, sehingga akan dapat mempengaruhi sifat fisik dari sediaan gel. Pada penelitian ini digunakan propilen glikol dan PEG-400 sebagai humektan. Dipilih kombinasi PEG-400 dan propilen glikol untuk meningkatkan fungsi keduanya sebagai humektan pada sediaan. Selain itu dengan viskositas yang rendah, propilen glikol dapat membantu penurunan viskositas yang terlalu tinggi akibat perpaduan antara carbopol 940 dan polivinil alkohol. Propilen glikol dan PEG-400 bersifat higroskopis dan memiliki viskositas cenderung rendah sehingga sesuai untuk sifat fisik yang diharapkan pada sediaan gel.

Dalam formula gel pada penelitian ini digunakan etanol $96 \%$ yang berfungsi sebagai pelarut dan memberikan sensasi dingin saat diaplikasikan di kulit. Sensasi dingin yang terjadi merupakan akibat dari evaporasi etanol dari sediaan karena terpapar suhu tubuh dan suhu lingkungan luar. Gel yang terbentuk transparan dan berwarna kuning karena sampel yang digunakan mengandung karotenoid yang merupakan pigmen kuning.

Pada formula sediaan gel ini digunakan metil paraben sebagai pengawet. Gel yang terbentuk merupakan sistem hidrogel yang memiliki kandungan air yang tinggi sehingga diperlukan adanya pengawet untuk menjaga stabilitas sediaan dan menghindari pertumbuhan mikroorganisme (Buchmann, 2001). Pada saat pembuatan gel, metil parabenterlebih dahulu dilarutkan dalam etanol 96\% Dalam setiap formula gel digunakan sebanyak $0,2 \%$ metil paraben, jumlah ini berada dalam batas aman yang diperbolehkan di Indonesia, yang tercantum dalam Lampiran IV Peraturan Kepala Badan POM RI No. HK. 00.05.42.1018 tentang bahan kosmetik. Batas maksimum kadar pengawet paraben dan turunannya yaitu $0,4 \%$ untuk ester tunggal dan $0,8 \%$ untuk ester campuran.

Formula masker gel peel off (Tabel 1) dibuat sebanyak 4 formula dengan polivinil alkohol sebagai pembentuk lapisan film sehingga lapisan film yang terbentuk dapat diangkat dengan mudah tanpa retak atau robek. Konsentrasi polivinil alkohol yang digunakan adalah level rendah $10 \%$ dan level tinggi $14 \%$. Propilen glikol digunakan sebagai humektan yang menjaga kestabilan sediaan gel dengan cara mengurangi penguapan air dari sediaan. Konsentrasi Propilen glikol yang digunakan adalah level rendah $10 \%$ dan level tinggi $21 \%$. Hasil evaluasi mutu fisik dan kimia meliputi daya sebar, $\mathrm{pH}$, viskositas dan lama mengering dianalisis secara statistik dengan uji one way Anova pada taraf kepercayaan $95 \%$ dan dilanjutkan uji lanjut Duncan multipe range tes $t$. Uji one way Anova pada taraf kepercayaan $95 \%$ dilakukan untuk mengetahui adanya perbedaan antara keempat formula yang kemudian dilanjutkan dengan uji lanjut Duncan untuk mengetahui formula yang optimum.

Tabel 1. Komposisi formula masker gel peel-off

\begin{tabular}{ccccc}
\hline Komponen Bahan $(\%)$ & F1 & F2 & F3 & F4 \\
\hline Carbopol 940 & 1 & 1 & 1 & 1 \\
PEG -400 & 6 & 6 & 6 & 6 \\
Polivinil alkohol & $\mathbf{1 0}$ & $\mathbf{1 4}$ & $\mathbf{1 0}$ & $\mathbf{1 4}$ \\
Propilen glikol & $\mathbf{1 0}$ & $\mathbf{1 0}$ & $\mathbf{2 1}$ & $\mathbf{2 1}$ \\
Trietanola-min $(\mathrm{g})$ & 0,5 & 0,5 & 0,5 & 0,5 \\
Serbuk sari labu kuning & 5 & 5 & 5 & 5 \\
Metil Paraben & 0,2 & 0,2 & 0,2 & 0,2 \\
Alkohol 96\% & 6 & 6 & 6 & 6 \\
Aquadest ad & 100 & 100 & 100 & 100 \\
\hline \multicolumn{4}{c}{ *Tiap formula direplikasi 3 kali }
\end{tabular}

Berdasarkan hasil evaluasi mutu fisik dan kimia masker gel peel-off (Tabel 2) menunjukkan bahwa pada pengujian daya sebar diperoleh nilai untuk $F_{1}(5,15), F_{2}(4,23)$, 
F3 $(4,93), F_{4}(4,38)$. Dari keempat formula hanya formula 1 yang memenuhi kriteria mutu fisik, hal ini didukung oleh pengolahan data statistik one way Anova yang menyatakan bahwa tidak ada perbedaan yang signifikan pada keempat formula terhadap daya sebar. Pada pengujian $\mathrm{pH}$ diperoleh nilai $\mathrm{F}_{1}(6,30), \mathrm{F}_{2}$ $(5,91), F_{3}(5,97), F_{4}(6,17)$. Keempat formula memenuhi kriteria mutu fisik. Pengolahan data statistik one way Anova menyatakan bahwa tidak ada perbedaan yang signifikan pada keempat formula terhadap $\mathrm{pH}$. Pada pengujian viskositas diperoleh nilai $F_{1}(15400), \quad F_{2}$ (66400), $F_{3}(62050), F_{4}(82900)$. Dari keempat formula hanya formula 1 yang memenuhi kriteria mutu fisik, hal ini juga didukung oleh pengolahan data statistik one way Anova yang menyatakan bahwa adanya perbedaan signifikan antara $F_{1}$ dengan $F_{2}, F_{3}, F_{4}$, dimana viskositas konsentrasi polivinilalkohol $14 \%$ dan konsentrasi propilen glikol $21 \%$ yang digunakan membuat sediaan menjadi lebih kental. Kemudian dilanjutkan dengan uji lanjut Duncan, dimana hasil pengujiandiketahui bahwa dari keempat formula hanya formula 1 yang hanya memenuhi kriteria. Pada pengujian lama pengeringan diperoleh nilai $\mathrm{F}_{1}(20,00), \mathrm{F}_{2}$ $(22,75), \quad F_{3} \quad(29,50), \quad F_{4}(21,25)$. Keempat formula memenuhi kriteria mutu fisik. Pada pengujian ini formula 1 adalah formula yang paling memenuhi kriteria karena waktu mengering lebih cepat daripada formula lainnya. Lama pengeringan juga dipengaruhi oleh konsentrasi polivinil alkohol dan Propilen glikol yang digunakan, dimana konsentrasi polivinil alkohol level tinggi $14 \%$ yang digunakan pada propilen glikol level rendah dan tinggi akan memperlama waktu pengeringan. Hal ini juga didukung oleh pengolahan data statistik one way Anova yang menyatakan bahwa tidak ada perbedaan signifikan antara F1, F2, F3 tetapi berbeda signifikan dengan F4. Karena terdapat perbedaan signifikan kemudiaan diuji lanjut dengan uji lanjut Duncan, diketahui bahwa formula 1 yang memenuhi kriteria. Berdasarkan hasil evaluasi dari keempat formula, yang memenuhi semua kriteria adalah formula 1 dengan konsentrasi polivinil alkohol sebagai pembentuk film $10 \%$ dan propilen glikol sebagai humektan 10\% dijadikan sebagai formula optimum masker gel peel-off sari buah labu kuning yang terpilih untuk diuji stabilitas mutu fisiknya selama 4 minggu dan dilakukan pengujian aktivitas antioksidan. Formula 1 memenuhi mutu fisik dan kimia sesuai dengan batasan masingmasing respon dalam penelitian ini yaitu daya sebarnya $5,15 \mathrm{~cm} \quad(5,0-7,0 \mathrm{~cm})$; lama pengeringan 20 menit (15 - 30 menit); $\mathrm{pH} 6,3$ $(4,5-6,5)$ dan viskositas $15.400 \mathrm{cps}(6000-$ $24000 \mathrm{cps})$.

Tabel 2. Hasil Evaluasi Mutu Fisik dan Kimia Masker Gel Peel Off

\begin{tabular}{ccccc}
\hline $\begin{array}{c}\text { Parameter Sifat } \\
\text { Fisik dan Kimia }\end{array}$ & F1 & F 2 & F 3 & F 4 \\
\hline $\begin{array}{c}\text { Daya Sebar (cm) } \\
\text { pH }\end{array}$ & $5,15 \pm 0,87^{\mathrm{a}}$ & $4,23 \pm 0,29^{\mathrm{a}}$ & $4,93 \pm 0,65^{\mathrm{a}}$ & $4,38 \pm 0,38^{\mathrm{a}}$ \\
$\begin{array}{c}\text { Viskositas (cps) } \\
\text { Lama }\end{array}$ & $15.400 \pm 0,47^{\mathrm{a}}$ & $5,91 \pm 0,02^{\mathrm{a}}$ & $5,97 \pm 0,03^{\mathrm{a}}$ & $6,17 \pm 0,04^{\mathrm{a}}$ \\
$\begin{array}{c}\text { Pengeringan } \\
\text { (menit) }\end{array}$ & $20,00 \pm 2,45^{\mathrm{a}}$ & $22,75 \pm 3,20^{\mathrm{a}}$ & $29,50 \pm 3,86^{\mathrm{b}}$ & $21,25 \pm 1,89^{\mathrm{a}}$ \\
\hline Ket : notasi yang berbeda menunjukkan adanya perbedaan yang signifikan & &
\end{tabular}

Pengujian mutu fisik dan kimia formula optimum dilakukan meliputi pengamatan organoleptis, homogenitas, daya sebar, $\mathrm{pH}$, viskositas dan lama pengeringan (Tabel 3). Pengamatan organoleptis dilakukan untuk mengamati perubahan-perubahan fisik sediaan yang terjadi meliputi warna aroma dan konsistensi sediaan. Sifat organoleptis sediaan stabil selama penyimpanan dimana tidak terjadi perubahan warna, aroma dan konsistensi sediaan. Pengujian homogenitas menunjukkan sediaan tetap homogen selama penyimpanan.

Pengujian daya sebar dilakukan untuk mengetahui kemampuan penyebaran maskergel peel off saat diaplikasikan ke kulit serta pengeluaran gel dari wadah. Pengujian ini untuk mengetahui seberapa luas area permukaan kulit yang dapat dijangkau oleh sediaan. Semakin besar nilai daya sebar masker menunjukkan bahwa konsistensi dari masker tersebut lebih lunak. Nilai daya sebar 
yang diinginkan untuk sediaan topikal adalah antara 5,0-7,0 cm (Garg dkk., 2002). Hasil pengujian dapat dilihat pada Tabel 3. Daya sebar berbanding terbalik dengan viskositas. Rerata daya sebar masker gel formula optimum yang diperoleh selama penyimpanan 4 minggu adalah $5,1 \mathrm{~cm}$. Daya sebar tetap stabil selama penyimpanan berdasarkan uji paired sample t test.

Pengujian $\mathrm{pH}$ ini bertujuan untuk mengetahui nilai keasaman masker dan mengetahui apakah $\mathrm{pH}$ masker telah sesuai dengan $\mathrm{pH}$ kulit. Hal ini berkaitan dengan keamanan sediaan saat digunakan, karena sediaan ini merupakan sediaan topikal yang akan digunakan di kulit wajah. $\mathrm{pH}$ sediaan sedapat mungkin sesuai $\mathrm{pH}$ kulit, yaitu 4,5-6,5 (Tranggono, 2007). pH sediaan yang terlalu asam akan menimbulkan iritasi kulit, sedangkan $\mathrm{pH}$ yang terlalu basa dapat menyebabkan efek kering pada kulit. Hasil pengujian dapat dilihat pada Tabel 3. Rerata pH masker gel selama 4 minggu penyimpanan adalah 5,7. pH tetap stabil selama penyimpanan berdasarkan uji paired sample $t$ test.

Viskositas sediaan merupakan parameter yang penting untuk menghasilkan gel yang optimal. Gel dengan viskositas terlalu rendah menyebabkan waktu kontak dengan kulit tidak cukup lama sehingga aktivitas bahan aktif tidak optimal, viskositas yang besar meningkatkan waktu retensi pada tempat aplikasi, tetapi juga menurunkan daya sebar. (Garg dkk., 2002). Pada pengujian viskositas alat yang digunakan adalah Viskometer Brookfield dan menggunakan spindel nomor 7 dengan kecepatan $20 \mathrm{rpm}$. Nilai viskositas yang diinginkan untuk sediaan topikal adalah 6000-24000 cps (Ameliawati, 2012). Besar viskositas suatu sediaan tergantung pada tujuan penggunaan sediaan tersebut. Sediaan yang digunakan untuk pengobatan biasanya lebih lembut. Sedangkan sediaan yang digunakan untuk melindungi kulit, memiliki konsistensi yang lebih kental. Hasil pengujian dapat dilihat pada Tabel 3. Rerata viskositas masker gel selama 4 minggu penyimpanan adalah $17,041 \mathrm{cps}$. $\mathrm{pH}$ tetap stabil selama penyimpanan berdasarkan uji paired sample $t$ test.

Uji lama pengeringan bertujuan untuk mengetahui waktu yang diperlukan oleh masker gel peel off untuk mengering setelah diaplikasikan ke kulit. Uji waktu mengering ini dilakukan karena masker gel peel-off diharapkan akan membentuk lapisan film dalam waktu tertentu setelah diaplikasikan. Lama pengeringan yang diharapkan dari masker gel peel-off yang dihasilkan adalah antara 15-30 menit (Nurrochmach, 2012). Hasil pengujian dapat dilihat pada Tabel 3. Rerata lama pengeringan masker gel selama 4 minggu penyimpanan adalah 25 menit. Lama pengeringan tetap stabil selama penyimpanan berdasarkan uji paired sample t test.

Tabel 3. Hasil Evaluasi Stabilitas Formula Optimum Masker Gel Peel-Off Sari Buah Labu Kuning

\begin{tabular}{cccccc}
\hline & & \multicolumn{4}{c}{$\begin{array}{c}\text { Hasil Pengamatan } \\
\text { (Rerata } \pm \text { SD) }\end{array}$} \\
\cline { 3 - 6 } Formula & Minggu & $\begin{array}{c}\text { Daya Sebar } \\
(\mathrm{cm})\end{array}$ & $\mathrm{pH}$ & $\begin{array}{c}\text { Viskositas } \\
(\mathrm{cPs})\end{array}$ & $\begin{array}{c}\text { Lama Pengeringan } \\
\text { (Menit) }\end{array}$ \\
\hline Masker & I & $4,9 \pm 0,05$ & $5,9 \pm 0,11$ & $16.666 \pm 416,33$ & $24 \pm 0,57$ \\
Gel Peel- & II & $5,2 \pm 0,12$ & $5,8 \pm 0,01$ & $16.666 \pm 416,33$ & $25 \pm 0,57$ \\
Off Labu & III & $5,2 \pm 0,14$ & $5,8 \pm 0,13$ & $17.666 \pm 416,33$ & $26 \pm 2,00$ \\
Kuning & IV & $5,1 \pm 0,02$ & $5,6 \pm 0,06$ & $17.167 \pm 288,68$ & $25 \pm 0,57$ \\
\hline
\end{tabular}

Pengujian aktivitas antioksidan sediaan masker gel peel-offdilakukan menggunakan metode DPPH. Masing-masing sampel dibuat dalam konsentrasi $80 \mathrm{ppm}$ untuk mendapatkan nilai absorbansi dan persen inhibisi terhadap DPPH. Data absorbansi dan persen inhibisi masing-masing sampel dapat dilihat pada Lampiran 8. Setelah mendapatkan data absorbansi selanjutnya dilakukan perhitungan persentase peredaman. Berdasarkan hasil yang diperoleh menunjukkan persentase peredaman masker gel peel-off sari buah labu kuning adalah sebesar $75,18 \%$ sedangkan aktivitas antioksidan masker betakaroten sebagai pembanding sebesar $76,47 \%$. Berdasarkan data tersebut menunjukkan nilai persen peredaman pada masing-masing formula 
termasuk dalam aktivitas antioksidan dengan intensitas kuat. Adanya aktivitas antioksidan disebabkan adanya kandungan betakaroten yang merupakan antioksidan yang kuat, yang dapat menjaring radikal bebas dalam tubuh dan menetralkannya sebelum radikal tersebut merusak sel. Menurut Coleman (2008), penggunaan betakaroten secara topikal telah terbukti dapat memperbaiki kerusakan kulit karena pengaruh sinar matahari dan menjaga kulit agar tetap sehat. Pengujian aktivitas antioksidan gel masker dilakukan setelah 2 hari pembuatan dan setelah 28 hari penyimpanan. Hasil reaksi antara larutan pereaksi DPPH dengan larutan uji menunjukkan perubahan warna dari ungu menjadi kuning, dimana $\mathrm{H}^{+}$merupakan atom hydrogen yang mengandung satu proton dan satu electron yang berasal dari senyawa peredaman radikal bebas yang bereaksi dengan DPPH membentuk senyawa DPPHidrazinyang stabil. Hasil yang diperoleh menunjukkan persen peredaman masker gel peel off sari buah labu kuning adalah 73,37\% dan gel masker betakaroten adalah 71,53\% dimana, masker gel mengalami perubahan signifikan setelah penyimpanan 4 minggu pada suhu ruang namun masih tergolong aktivitas antioksidan tinggi. Penurunan ini diduga karena terjadinya proses oksidasi selama penyimpanan akibat pengaruh udara karena menggunakan wadah yang kurang kedap udara.

Tabel 4. Hasil Uji Aktivitas Antioksidan Masker Gel Peel Off Sari Buah Labu Kuning

\begin{tabular}{ccc}
\hline & \multicolumn{2}{c}{ Persen Peredaman (\%) Hari Ke- } \\
\cline { 2 - 3 } Formula & 2 & 30 \\
\hline $\begin{array}{c}\text { Masker Gel Peel-Off Sari Buah } \\
\text { Labuning }\end{array}$ & 75.18 & $73.37^{*}$ \\
Masker Gel Peel-off Betakaroten & 76.47 & $71.53^{*}$ \\
\hline
\end{tabular}

Ket : $:$ ada perbedaan signifikan dibanding hari ke-2 


\section{UCAPAN TERIMA KASIH}

Terima kasih saya ucapkan kepada kak Iyan Santoso dan Istigfarin selaku laboran yang telah banyak membantu selama penelitian.

\section{DAFTAR PUSTAKA}

Ameliawati. (2012). Prediksi komposisi optimum film agent polivinil alkohol dan humectan gliserin dalam formula gel masker peel-off antiacne ekstrak etanol daun siri (Piper betle L)- Aplikasi desain faktorial.. (Skripsi) Universitas Sanata Dharma. Yogyakarta

Buchmann, (2001). Main Cosmetic Vehicles, dalam Barel, A.O., Paye, M., dan Maibach, H.I (Eds), Handbook of Cosmetic Science and Technology, Marcell Dekker Inc., New York.

Cahyanti, F. (2013). Aktivitas antioksidan dan uji stabilitas fisik krim sari labu kuning (Cucurbita moschata Duchesne). (Skripsi) Universitas Tadulako Palu.

Coleman, B. (2009). Food source of beta carotene for healthy skin; repair sun damage with carrot and sweet potatos, republication from balch, p.a, 2006, presscription for nutritional healing $4^{\text {th }}$. Diakses dari suite 101.com. tgl 20 Februari 2015.

Garg, A., Aggarwal, D., Garg, S., and Singla, A. (2002). Spreading of semisolid formulation: An Update pharmaceutical technology.

Kandlakunta, B., Rajendran, A., and Thingnganing, L. (2008). Carotene content of some common (cereals, pulses, vegetables, sp ices and condiments) and unconventional sources of plant origin. food chemistry.

Martin, A. (1993). Farmasi Fisik Edisi ke-III. Terjemahan dari Phisical Pharmacy. Oleh Joshita. Jakarta: UI Press.

Nurrochmah, B., (2012). Optimasi film agent polyvinyl alcohol dan humektan gliserin dalam formula gel masker peel-off antiacne dari ekstrak daun kemangi (Ocimum sanctum L.): Aplikasi desain faktorial, (Skripsi) Universitas Sanata Dharma, Yogyakarta.

Ogur,E. (2005). Polyvinyl Alcohol: Materials, Processing and Applications Volume 16. Diakses pada tanggal 15 Juni 2015.

Rowe. (2009). Handbook of pharmaceutical excipients sixth edition. Washington: Pharmaceutical Press and American Pharmacists Association.

Safitri, Rizki, (2011). Penggunaan buah labu kuning (Cucubita moschata Duchesne) dalam sediaan krim pelembab, (Skripsi) Fakultas. Farmasi. USU, Medan.

Tranggono, R., I. dan Latifah F. (2007). Buku Pegangan Ilmu Pengetahuan Kosmetik. Jakarta: PT Gramedia Pustaka Utama.

Wahyuni, T., D, \& Widjanarko, B., S. (2015). Pengaruh jenis pelarut dan lama ekstraksi terhadap ekstrak karotenoid labu kuning dengan metode gelombang ultrasonik. (Skripsi) Universitar Brawijaya Malang. 